\title{
Encapsulation of Bifidobacterium longum in alginate-dairy matrices and survival in simulated gastrointestinal conditions, refrigeration, cow milk and goat milk
}

Article

Accepted Version

Creative Commons: Attribution-Noncommercial-No Derivative Works 4.0

Prasanna, P. H. P. and Charalampopoulos, D. (2018) Encapsulation of Bifidobacterium longum in alginate-dairy matrices and survival in simulated gastrointestinal conditions, refrigeration, cow milk and goat milk. Food Bioscience, 21. pp. 72-79. ISSN 2212-4292 doi:

https://doi.org/10.1016/j.fbio.2017.12.002 Available at https://centaur.reading.ac.uk/74692/

It is advisable to refer to the publisher's version if you intend to cite from the work. See Guidance on citing.

Published version at: http://dx.doi.org/10.1016/j.fbio.2017.12.002

To link to this article DOI: http://dx.doi.org/10.1016/j.fbio.2017.12.002

Publisher: Elsevier

All outputs in CentAUR are protected by Intellectual Property Rights law, including copyright law. Copyright and IPR is retained by the creators or other copyright holders. Terms and conditions for use of this material are defined in the End User Agreement. 


\section{www.reading.ac.uk/centaur}

\section{CentAUR}

Central Archive at the University of Reading

Reading's research outputs online 
1 Encapsulation of Bifidobacterium longum in alginate-dairy matrices and 2 survival in simulated gastrointestinal conditions, refrigeration, cow milk and goat milk

4

5 Running title: Encapsulation of bifidobacteria in alginate-dairy based 6 matrices

7 P.H.P. Prasanna ${ }^{a, b^{*}}$, D. Charalampopoulos ${ }^{a}$

$8 \quad{ }^{a}$ Department of Food and Nutritional Sciences, University of Reading, Whiteknights,

9 Reading, RG6 6AP, UK

$10{ }^{b}$ Department of Animal and Food Sciences, Faculty of Agriculture, Rajarata University of

11 Sri Lanka, Puliyankulama, Anuradhapura, Sri Lanka

12

13 "Corresponding author:

14 P.H.P. Prasanna

15 Department of Animal and Food Sciences, Faculty of Agriculture, Rajarata University of Sri

16 Lanka, Puliyankulama, Anuradhapura, Sri Lanka.

17 Tele:0094714458656

18 Fax:0094252221614

19 Email:phpprasanna@yahoo.com

20

21

22

23 


\section{Abstract}

25 The aim of this study was to microencapsulate Bifidobacterium longum subsp. infantis CCUG 2652486 using the extrusion method in a variety of matrices, namely sodium alginate (SA), 27 sodium alginate-cow milk (SACM), sodium alginate-goat milk (SAGM) and sodium alginatecasein hydrolysate $(\mathrm{SACH})$, and to evaluate the survival of free and encapsulated bacterial cells under different conditions. The encapsulation yield, size and surface morphology of the microcapsules were evaluated. The survival of microencapsulated bacterial cells and free bacterial cells were evaluated under simulated gastrointestinal conditions as well as in refrigeration, cow milk and goat milk during storage at $4{ }^{\circ} \mathrm{C}$ for 28 days. The average size of

33 SACM capsules and SAGM capsules was $2.8 \pm 0.3 \mathrm{~mm}$ and $3.1 \pm 0.2 \mathrm{~mm}$ respectively. Goat milk and cow milk based matrices resulted in dense microcapsules which led to better performances in simulated gastrointestinal conditions than SA and SACH microcapsules. The bacterial cells encapsulated in SAGM showed the highest survival rate in cow milk (7.61 log $\left.\mathrm{cfu}^{-1}\right)$ and goat milk (8.10 $\operatorname{log~cfu~g}^{-1}$ ) after the storage of $28 \mathrm{~d}$. The cells encapsulated in SA and $\mathrm{SACH}$ and the free cells performed poorly under the simulated gastrointestinal conditions and in all different storage conditions. This study showed that SACM and SAGM are suitable to encapsulate B. longum subsp. infantis CCUG 52486 using the extrusion technique and more specifically, SAGM has a potential to be used as a new encapsulation material for encapsulating probiotic bacteria, resulting milk and goat milk-based products with higher probiotic cell concentrations during refrigerated storage. 


\section{1. Introduction}

Bifidobacteria are a major group of probiotic microorganisms, which have been widely researched for their probiotic properties. Bifidobacteria are considered to exert many beneficial effects to the human host such as alleviation of lactose intolerance, reduction of serum cholesterol levels, synthesis of some vitamins, prevention of colonization of pathogens, modulation of the immune system, reduction of symptoms of irritable bowel disease, and prevention of diarrhoea (Shah, 2007; Xiao et al., 2003). They have been shown to be suitable for incorporation as a co-starter in different food products including dairy-based food formulations (Bunesova et al., 2015; Prasanna et al., 2014). The therapeutic concentration of probiotic bacteria in a product should be around $6 \log$ CFU g-1 until the end of their shelf life (Donkor et al., 2006). In addition, bifidobacteria must endure the high acidic condition in the stomach and hydrolytic enzymes and bile salts in the small intestine prior to reaching the colon in large quantities, which is essential for effective permanent or transient colonization of bacteria (Song et al., 2013). Furthermore, most strains of bifidobacteria show poor growth and viability in milk and fermented milk products (Ranadheera et al., 2014).

In this context, microencapsulation has been widely researched to create a physical barrier protecting the bacteria from adverse conditions during production processes and digestion (Fritzen-Freire et al., 2012). There are many microencapsulation techniques which have been used with probiotics such as emulsion, extrusion, spray drying, freeze drying, coacervation, fluidized bed coating and phase separation (Rajam et al., 2012). Most of these techniques involve harsh processing conditions, which directly affect the viability and the performances of the encapsulated probiotic bacteria. However, the extrusion method involves mild conditions during probiotic encapsulation (Shi et al., 2013a). In this method, a hydrocolloid solution containing concentrated probiotic bacteria is dropped into a solidifying solution. Sodium alginate obtained from brown seaweed has been widely researched as an encapsulation material for probiotics. However, alginate cannot protect effectively probiotic bacteria from the highly acidic environment due to the porous structure of alginate beads, which supports the easy diffusion of acid and other materials inside (Rajam et al., 2012). Therefore, it is recommended to blend or coat alginate with other filler materials to overcome the above-mentioned disadvantages (Cook et al., 2013). 
Many studies have reported the effectiveness of different alginate based matrices for microencapsulation of probiotic, such as alginate-starch (Sultana et al., 2000), alginatechitosan (Chávarri et al., 2010; Krasaekoopt et al., 2004), alginate-gelatin (Li et al., 2009), alginate-pectin (Sandoval-Castilla et al., 2010) and alginate-whey protein (Gbassi et al., 2009). In addition, there has been a considerable interest in using dairy-based matrices to encapsulate probiotic bacteria, since these materials contain lactose and proteins which can provide good protection for cells during the handling and digestion process (Maciel et al., 2014). Milk and milk proteins are used in many food formulations and are widely accepted by consumers due to unique physicochemical properties. In the context of encapsulation, milk and milk proteins have technological properties such as high buffering capacity, good emulsification properties and the ability to make networks, even at low concentration (Würth et al., 2015). In addition, it is reported that microcapsules containing dairy proteins can lead to higher bacterial survival during digestion (Burgain et al., 2014). Furthermore, usage of milk based materials for encapsulation of microorganisms would be suitable to be used in dairy-based food products with improved physicochemical properties (Ranadheera et al., 2016). Therefore, there is a high potential to use different milk types and milk based proteins with alginate to encapsulate, protect and control the release of probiotic bacteria in the digestive tract (Özer et al., 2009; Ranadheera et al., 2015).

However, there are few recorded reports on the effect of different alginate-dairy based matrices on encapsulation of bifidobacteria. In addition, to the best of authors' knowledge goat milk has not been used with alginate to encapsulate bifidobacteria using the extrusion technique.

100 Therefore, the aim of this study was to evaluate the survival of Bifidobacterium longum subsp. infantis CCUG 52486 encapsulated in sodium alginate, sodium alginate-cow milk, sodium alginate-goat milk and sodium alginate-casein hydrolysate in simulated gastrointestinal conditions and during storage in cow milk, goat milk and refrigeration at $4{ }^{\circ} \mathrm{C}$ for 28 days. This Bifidobacterium strain was selected as in our previous studies, it was shown to produce an exopolysaccharide (EPS) in milk (Prasanna et al., 2012) and to improve the physicochemical and rheological properties of low-fat set yoghurt (Prasanna et al., 2013). In addition, this strain

107 has been characterized as a probiotic strain (Gougoulias et al., 2008) and to have a high a high angiotensin-I-converting enzyme (ACE) inhibitory activity in fermented milk (GonzalezGonzalez et al., 2011) 


\section{2. Materials and methods}

\section{2 \\ 2.1. Bacterial strain and growth conditions}

113 B. longum subsp. infantis CCUG 52486 was obtained from the culture collection of the

114 University of Göteborg in Sweden. The cell bank of microorganism was stored at $-80{ }^{\circ} \mathrm{C}$ in

115 Wilkins-Chalgren (WC) anaerobe broth (Oxoid, Hampshire, UK) containing 15\% (v/v)

116 glycerol. The frozen stock was initially propagated in Bifidobacteria Selective Medium (BSM)

117 agar (Sigma-Aldrich, Dorset, UK) under anaerobic conditions at $37{ }^{\circ} \mathrm{C}$ for $72 \mathrm{~h}$. Two

118 successive cultures of bacteria were carried out in WC broth (Oxoid, UK) under anaerobic

119 condition at $37^{\circ} \mathrm{C}$ for $18 \mathrm{~h}$. Subsequently, a cell aliquot of the preculture $(1 \%, \mathrm{v} / \mathrm{v})$ was used

120 to inoculate $200 \mathrm{~mL}$ of WC broth (Oxoid, UK) and incubated at $37^{\circ} \mathrm{C}$ for $18 \mathrm{~h}$ under anaerobic

121 condition. Bacterial cells were harvested after by centrifugation at 10,000 rpm for $10 \mathrm{~min}$ at 4

$122{ }^{\circ} \mathrm{C}$. The pellet was washed with sterile phosphate buffered saline (PBS) (Oxoid, UK) and 123 aseptically resuspended in $10 \mathrm{~mL}$ of PBS (Oxoid, UK) to prepare the concentrated cell 124 suspension.

\subsection{Encapsulation of B. longum subsp. infantis CCUG 52486}

Sterilized cow milk and sterilized goat milk were purchased from a local supermarket. Casein hydrolysate solution $(2 \%, \mathrm{w} / \mathrm{v}$, Sigma-Aldrich, UK) and sodium alginate solution $(2 \%, \mathrm{w} / \mathrm{v}$, low viscosity, Sigma-Aldrich, UK) were sterilized at $121{ }^{\circ} \mathrm{C}$ for $15 \mathrm{~min}$. Three different

130 alginate-dairy based microsphere formulations were prepared. They were SACM (sodium alginate/cow milk $=1.5 / 1, \mathrm{v} / \mathrm{v}), \mathrm{SAGM}($ sodium alginate/goat milk $=1.5 / 1, \mathrm{v} / \mathrm{v}$ ) and $\mathrm{SACH}$ (sodium alginate/casein hydrolysate $=1.5 / 1, \mathrm{v} / \mathrm{v}$ ); SA (sodium alginate) was used as the control. Each alginate-based formulation was mixed with the concentrated cell suspension at a ratio of 4:1 (alginate-based mixture solution: the concentrated cell suspension, v/v). In the case of free cells, $10 \mathrm{~mL}$ of the concentrated cell suspension was mixed with $40 \mathrm{~mL}$ of PBS (Oxoid,

$136 \mathrm{UK})$. The hydrocolloid-cell suspensions were dropped through a $21 \mathrm{G}$ needle into sterile $0.1 \mathrm{M}$

$137 \mathrm{CaCl}_{2}$ (Sigma-Aldrich, UK) under gentle stirring; the dropping height was $10 \mathrm{~cm}$. 138 Microcapsules were allowed to harden for 30 minutes and were then washed with sterile PBS 139 (Oxoid, UK) and stored in sterilized plastic containers at $4{ }^{\circ} \mathrm{C}$. The cell concentration encapsulated in the microcapsules was around $9 \log \mathrm{cfu} \mathrm{g}^{-1}$. 
143 The encapsulation yield (EY) was determined using the following equation. EY = (Number of

144 cells released from microcapsules) / (Number of cells added to the respective alginate based 145 microsphere formulation) X 100. The size of different microcapsules was measured using a 146 vernier caliper. For this, 30 microcapsules were randomly selected from each microsphere 147 formulation to calculate the mean size.

\subsection{Determination of viability of free and encapsulated bacteria}

150 Samples of free B. longum subsp. infantis cells were serially diluted in PBS (Oxoid, UK) and $100 \mu \mathrm{L}$ aliquots were plated on BSM agar (Sigma-Aldrich, UK) to enumerate the viable bacterial counts. The plates were incubated under anaerobic conditions at $37{ }^{\circ} \mathrm{C}$ for $72 \mathrm{~h}$. In the case of encapsulated bacteria, the samples were completely dissolved in sterilized $50 \mathrm{mM}$ sodium citrate (Sigma-Aldrich, UK) solution at $\mathrm{pH} 7.5$ before plating as described by Shi et al. (2013a). For this, $1 \mathrm{~g}$ of the encapsulated bacteria was dissolved in $9 \mathrm{~mL}$ sodium citrate and the samples were serially diluted in PBS (Oxoid, UK). Aliquots of $100 \mu \mathrm{L}$ of the serially diluted sample were plated on BSM agar (Sigma-Aldrich, UK) and after incubation, the viable cell counts were enumerated.

\subsection{Survival of free and encapsulated bacteria in simulated gastrointestinal conditions}

161 Simulated gastric juice (SGJ) was prepared by dissolving $0.2 \% \mathrm{NaCl}(\mathrm{w} / \mathrm{v})$ in $0.08 \mathrm{M} \mathrm{HCl}$, at pH 2 as described by Sun and Griffiths (2000). The microcapsules ( $1 \mathrm{~g})$ or the free cells $(1 \mathrm{~mL})$ were added to glass tubes containing $9 \mathrm{~mL}$ of sterilized SGJ and placed in a water bath at 37 ${ }^{\circ} \mathrm{C}$. Samples were taken at 0, 30, 60 and $120 \mathrm{~min}$, during incubation. For the free cells, the samples were taken and centrifuged at $10,000 \mathrm{rpm}$ for $10 \mathrm{~min}$, at $4{ }^{\circ} \mathrm{C}$. The pellet was dissolved in PBS (Oxoid, UK) and used for cell enumeration. In the case of microencapsulated bacterial cells, the microcapsules were separated from the samples and dissolved in sodium citrate (50 $\mathrm{mM}$ ) before plating. For enumeration, all samples were serially diluted in PBS (Oxoid, UK) and viable cells were enumerated as described in Section 2.4.

171 Simulated intestinal juice (SIJ) was prepared as described by Chávarri et al. (2010). For this, 3 
$173 \mathrm{NaCl}, 0.835 \mathrm{~g} / \mathrm{L} \mathrm{KCl}, 0.22 \mathrm{~g} / \mathrm{L} \mathrm{CaCl}_{2}$ and $\left.1.386 \mathrm{~g} / \mathrm{L} \mathrm{NaHCO}_{3}\right)$, at $\mathrm{pH}$ 7.5. Microcapsules $(1 \mathrm{~g})$

174 or the free cells $(1 \mathrm{~mL})$ were added to glass tubes containing $9 \mathrm{~mL}$ of sterilized SIJ and placed

175 in a water bath at $37{ }^{\circ} \mathrm{C}$. The sampling and enumeration of free and encapsulated B. longum

176 subsp. infantis CCUG 52486 were carried out as described previously.

177

178 2.6. Survival of free and microencapsulated bacterial cells in refrigeration, cow milk and goat milk during refrigerated storage

180 In the case of refrigerated storage, microcapsules or free cells were stored (1 $\mathrm{g}$ for microcapsules/ $1 \mathrm{~mL}$ for free cells in each portion) in sterilized centrifuge tubes $(15 \mathrm{~mL}$ capacity, polypropylene, Fisher Scientific, Loughborough, UK), at $4{ }^{\circ} \mathrm{C}$ for 28 days. In the case of cow milk, $1 \mathrm{~mL}$ of the free cells or $1 \mathrm{~g}$ of the encapsulated bacteria was mixed with $10 \mathrm{~mL}$ of sterilized cow milk in sterilized centrifuge tubes $(15 \mathrm{~mL}$ capacity, polypropylene, Fisher Scientific, UK). In the case of goat milk, $10 \mathrm{~mL}$ of sterilized goat milk in sterilized centrifuge tubes $(15 \mathrm{~mL}$ capacity, polypropylene, Fisher Scientific, UK) were mixed with $1 \mathrm{~mL}$ of the free cells or $1 \mathrm{~g}$ of the encapsulated cells. The centrifuge tubes containing free and encapsulated bacteria and inoculated milk samples were stored at $4{ }^{\circ} \mathrm{C}$ for 28 days. Afterwards, the samples were collected on $0,7,14,21$ and 28 days and analyzed for the viability of cells as described in Section 2.4.

\subsection{Scanning electron microscopic (SEM) analysis of surface of microcapsules}

The microcapsules were dehydrated sequentially in a series of ethanol solutions $(30,50,70$, 80,90 , and $100 \%$ ). For this, the microcapsules were soaked for 15 minutes in each solution. The dehydrated microcapsules were critical point dried using a critical point dryer (Balzers CPD 030, Liechtenstein, Germany) with liquid carbon dioxide. The dried samples were fixed to the SEM stubs with double-sided tape. Afterward, the microcapsules were gold coated using an Edwards S150B sputter-coater for 2.5 min (Edwards, West Sussex, UK). The surface of coated microcapsules was examined using a scanning electron microscope (FEI, Quanta 600 F, USA).

\subsection{Statistical analysis}

203 All the experiments were conducted in triplicate. Results of the size of microcapsules and encapsulation efficiency were analyzed using one-way analysis of variance (ANOVA) with 
205 Turkey's multiple comparison tests (SAS, version 9.2, SAS Institute Inc., Cary NC, USA). 206 Results of viable counts from simulated gastrointestinal conditions and from storage studies 207 were analyzed as a split-plot in time design using the General Linear Model (GLM) procedure 208 of SAS, version 9.2 (SAS Institute Inc., Cary NC, USA).

209

210 3. Results and discussion

211 3.1. Size, encapsulation yield and surface morphology of microcapsules 212 
213 Table 1 shows the size of the different microcapsules. The type of encapsulation material had

214 a significant influence $(p<0.05)$ on the size of microcapsules. The largest microcapsules were 215 observed with SAGM while their sizes were not significantly different $(p>0.05)$ with those of 216 SACM microcapsules. The smallest microcapsules in this study were observed with SA 217 though, the value was not significantly different with that of SACH. There is no published 218 literature to compare with the size of SAGM microcapsules, which have been prepared using 219 the extrusion technique. Our results showed that the addition of goat milk and cow milk to 220 sodium alginate resulted larger microcapsules than SA and SACH. This may be due to the 221 higher protein content of cow milk and goat milk which, can lead to higher total protein content 222 of SACM and SAGM. Similarly, Klemmer et al. (2011) and Shi et al. (2013a) reported that the 223 higher protein content in matrices could lead to larger microcapsules.

225 The type of encapsulating matrices had no significant $(p>0.05)$ effect on the encapsulation 226 yield ( 
Table 1) and the values ranged from $94.1 \%$ to $95.6 \%$. Our results are in accordance with findings of Pan et al. (2013) who reported around 99\% of the encapsulation efficiency of bacteria with alginate-skim milk. The results clearly showed that there was a very low loss of cell viability during the encapsulation which was due to the mild conditions used. In general, extrusion method is commonly used with hydrocolloids and reported to yield higher encapsulation yield (Krasaekoopt et al., 2003).

The surface morphology of the microcapsules was investigated using SEM micrographs. Fig.1 shows the surface of different microcapsules at a magnification of 10000. Porous microcapsules were observed with SA [Fig.1 (A)]. Furthermore, SA microcapsules had cracks on their surface and could not protect entrapped cells from adverse environmental conditions. Similarly, Li et al. (2009) reported porous structure for microcapsules produced using alginate. Modification of alginate with cow milk and goat milk resulted in the microcapsules (SACM, SAGM) with denser surface morphology [Fig.1 (B) and (C)]. In addition, these microcapsules did not have cracks that could ensure high protection for encapsulated cells from adverse conditions. SACH microcapsules showed irregular surface morphology [Fig.1 (D)] which could not give better protection for entrapped cells than that of SACM and SAGM microcapsules.

3.2. Survival of free and encapsulated B. longum subsp. infantis CCUG 52486 in simulated gastric juice

248 Microencapsulation provided a significant protection for the cells in simulated gastric juice (Fig. 2). The viable cell count of free B. longum subsp. infantis CCUG decreased significantly $(p<0.05)$ within 90 min of the incubation period and the cell count of free cells dropped to an undetectable level $\left(<10^{1} \mathrm{cfu} \mathrm{mL}^{-1}\right)$ after $120 \mathrm{~min}$. This is because bifidobacteria are fastidious organisms which are sensitive to acidic environment leading to challenges in industrial applications. Similarly, Lee and Heo (2000) observed a rapid reduction of the cell viability of free B. longum KCTC 3128 within 30 min when exposed to a simulated gastric environment. The present study also demonstrated that sodium alginate itself could not protect $B$. longum subsp. infantis CCUG from the highly acidic environment for a long time. Alginate is a copolymer and composed of D-mannuronic and L-guluronic acids. This copolymer is not stable at low pH condition (Liserre et al., 2007). Dissolution and erosion of alginate occur at low pH 
and lead for destruction of capsule structure. Our results are in accordance with findings of Krasaekoopt et al. (2004) and who reported poor viability of bacterial cells microencapsulated with alginate in simulated gastric juice. The results clearly showed that microencapsulation with SACM and SAGM gave a better protection for the cells than SA and SACH. The viable cell counts of SACM and SAGM microcapsules were $6.37 \log \mathrm{cfu} \mathrm{g}^{-1}$ and $5.19 \log \mathrm{cfu} \mathrm{\textrm {g } ^ { - 1 }}$ respectively, after $120 \mathrm{~min}$. The better protection observed in microencapsulated bacterial cells by cow milk and goat milk based matrices may be due to the high buffering capacity of milk proteins. In addition, milk proteins can interact with alginate and act as filling materials which can seal the porous structure of alginate-milk based microcapsules (Kailasapathy, 2006). Our results are in accordance with observations made in some other studies. Guérin et al. (2003) reported that the encapsulated bifidobacteria in a mixed gel made of alginate, pectin and whey proteins could survive better in simulated gastric juice at $\mathrm{pH} 2.5$ due to buffering activities of whey proteins.

\subsection{Survival of free and encapsulated bacterial cells in simulated intestinal juice}

The survival of free and encapsulated B. longum subsp. infantis CCUG 52486 in simulated intestinal juice at $37^{\circ} \mathrm{C}$ for $2 \mathrm{~h}$ is presented in Fig. 3. Encapsulation gave a significant $(p<0.05)$ protection for bacterial cells in simulated intestinal juice. The viable count of free cells showed a significant $(p<0.05)$ decrease within $120 \mathrm{~min}$. This may be due to the interaction of bile salt with the free cells leading to lose of cell wall integrity. The loss of cell wall integrity may lead to leakage of intercellular materials from the cells leading for death of cells (Bron et al., 2004). Similarly, Clark and Martin (1994) reported a rapid decrease of the viability of free cells of $B$. adolescentis in $2 \%$ bile salt solution at $37^{\circ} \mathrm{C}$.

Milk based microcapsules (SACM and SAGM) were the most effective in protecting the cells in simulated intestinal juice. It is due to milk ingredients, which can modify the textural properties of alginate-milk based matrices [Fig.1 (B) and (C)], as the modified matrices resist the diffusion of bile salt into the microcapsules. Similarly, alginate-milk based matrices were shown to be effective in protection of Lactobacillus bulgaricus (Shi et al., 2013a; Shi et al., 2013b) and Enterococcus faecalis (Shi et al., 2016) in simulated intestinal solution. SA and $\mathrm{SACH}$ microcapsules provided a limited protection for bacterial cells during the incubation period. This is due to the poor structure of those matrices [Fig.1 (A) and (D)], which can allow 
291 diffusion of bile salt into the microcapsules (Hansen et al., 2002; Lee and Heo, 2000).

292 Similarly, Krasaekoopt et al. (2004) reported poor viability of B. bifidum ATCC 1994

293 capsulated in alginate matrices when exposed to bile salt solution.

\subsection{Stability of free and encapsulated bacteria cells under refrigerated condition}

296 Fig. 4 shows the viability of free and encapsulated B. longum subsp. infantis CCUG 52486

297 with different alginate-based matrices during the refrigerated storage at $4{ }^{\circ} \mathrm{C}$. The cell concentration of free B. longum subsp. infantis CCUG 52486 decreased significantly $(p<0.05)$ from $8.96 \log \mathrm{cfu} \mathrm{g}^{-1}$ to $3.62 \log \mathrm{cfu} \mathrm{g}^{-1}$, indicating the inability of the free cells to maintain their viability under the refrigerated storage condition. The results further revealed that encapsulation could improve the viability of bacterial cells during refrigerated storage for 28 days. SA and SACH microcapsules showed higher cell viability than that of the free cells during the refrigerated storage. However, they were unable to maintain the viability of cells during the storage above the recommended count of $6 \log \mathrm{cfu}^{-1}$. Similarly, some studies reported that encapsulation of probiotic bacteria in sodium alginate could improve the storage stability of bacterial cells than that of the free cells (Chávarri et al., 2010; Krasaekoopt et al., 2004).

SACM and SAGM microcapsules gave better protection for the cells during the refrigerated storage and both materials were able to maintain the cell concentrations above $6 \log \mathrm{cfu} \mathrm{g}^{-1}$ after 28 days of storage than SA and SACH. However, the final cell counts of these two microcapsules were not significantly different $(p<0.05)$. This may be due to the denser surface morphology of alginate-dairy microcapsules [Fig.1 (B) and (C)], which can protect the encapsulated cells from adverse conditions of the environment. Similarly, some other alginatebased microcapsules have been shown to be effective to give better protection for probiotics during the refrigerated storage. Encapsulation of Lactobacillus gasseri and B. bifidum in chitosan-coated alginate microspheres was shown to be effective to maintain viability throughout the storage period at $4{ }^{\circ} \mathrm{C}$ for 28 days (Chávarri et al., 2010). In addition, Zou et al. (2011) showed that chitosan-coated alginate microspheres provided a better protection for the microencapsulated B. bifidum F-35 cells than that of the free cells during the storage at $4{ }^{\circ} \mathrm{C}$ for 1 month. 


\subsection{Survival of free and encapsulated bacterial cells in cow milk and goat milk at $4{ }^{\circ} \mathrm{C}$}

324 Table 2 shows the survival of free and encapsulated stored in cow milk at $4{ }^{\circ} \mathrm{C}$ for 28 days. The results indicated that encapsulation improved the survival of bacterial cells in cow milk during storage. The free cells showed poor storage stability in cow milk where the cell concentration was significantly $(\mathrm{p}<0.05)$ reduced from $8.65 \log \mathrm{cfu} \mathrm{mL} \mathrm{L}^{-1}$ to $4.38 \log \mathrm{cfu} \mathrm{mL} \mathrm{m}^{-1}$ within 28 days. SAGM microcapsules gave the best protection for the cells followed by SACM microcapsules. However, SA and SACH microcapsules could give a limited protection during the storage in cow milk. Fig. 5 shows the results of free and encapsulated bacterial counts in goat milk during storage at $4{ }^{\circ} \mathrm{C}$ for 28 days. There was a significant reduction $(p<0.05)$ in the viability of free cells during the storage. However, the results revealed that encapsulation of $B$. longum subsp. infantis CCUG 52486 improved the survival of bacterial cells in goat milk during the storage period of 28 days. The highest survival of bacterial cells during the storage was observed with SAGM microcapsules followed by SACM microcapsules; where they maintained the viability of bacterial cells above $6 \operatorname{log~cfu~g}^{-1}$ in goat milk during the storage period. Viable cell counts of SA and SACH microcapsules rapidly declined with the storage.

Poor viability of free cells in cow milk and goat milk is due to lack of availability of small peptides and free amino acids for their growth (Gomes et al., 1998; Martín-Diana et al., 2003). In this study, pure goat milk and cow milk were used to inoculate bacteria without any supplementation. Similarly, Hansen et al. (2002) observed poor viability of free B. longum Bb46 cells in milk during storage at $4{ }^{\circ} \mathrm{C}$ for 16 days than that of encapsulated bacterial cells. The poor survival of bacterial cells encapsulated in SA and SACH is due to the fragile texture of walls of these microcapsules [Fig.1 (A) and (D)], which exposes bacterial cells to the external environment. The high survival rate observed with microencapsulated bacterial cells with SACM and SAGM [Fig.1 (B) and (C)] in cow milk and goat milk may be due to improved denser surface characteristics compared to SA and SACH. The modified structure of SACM and SASM could protect their content form the adverse external environments. There is no recognized published literature about the survival of bifidobacteria encapsulated using alginate-milk based matrices in goat milk during storage to compare with our results. However, some authors have reported that encapsulation can improve the viability of bifidobacteria in cow milk and cow milk-based products. Hansen et al. (2002) showed the effectiveness of alginate microcapsules to improve the viability of B. longum Bb-46 in cow milk during the storage at $4{ }^{\circ} \mathrm{C}$ for 16 days. In another study, B. bifidum encapsulated in alginate beads coated 
with chitosan was shown to have better survival than the free cell in yoghurt after the storage at $4{ }^{\circ} \mathrm{C}$ for 4 weeks (Krasaekoopt et al., 2006). In addition Kailasapathy (2006) showed that the alginate-starch encapsulated B. lactis had higher survival than the free cells in yoghurt at $4{ }^{\circ} \mathrm{C}$ for 7 weeks.

360

361 The present study demonstrates that encapsulation of B. longum subsp. infantis CCUG 52486 in SACM and SAGM microcapsules beneficially influences the viability of bacterial cells in cow milk and goat milk during the storage at $4{ }^{\circ} \mathrm{C}$ for 28 days. Therefore, microencapsulation of bifidobacteria with SACM and SAGM could be used to enhance the growth of them in nonfermented cow milk and goat milk based products. Further studies should be carried out to evaluate the effect of encapsulation of bifidobacteria with SACM and SAGM microcapsules in fermented milk-based products and other food systems.

\section{Conclusions}

370

The mixing of alginate with cow milk and goat milk resulted in microcapsules with denser surface and the cells encapsulated in these matrices performed better in simulated gastrointestinal conditions than the bacterial cells encapsulated in SA and SACH microcapsules. Improved structural characteristics of SACM and SAGM microcapsules could improve survival of encapsulated bacterial cells in cow milk, goat milk and refrigeration at 4 ${ }^{\circ} \mathrm{C}$ for 28 days compared to SA and SACH microcapsules. Overall, this study showed that mixing of goat milk and cow milk with alginate improved the protection provided by modified microcapsules and could be used to improve survival of probiotic bacteria in non-fermented cow milk and goat milk based products.

\section{Acknowledgements}

381 P.H.P. Prasanna is a Commonwealth Academic Fellow, funded by the UK government. The technical assistance with SEM by the Centre for Advanced Microscopy (CfAM), University of Reading, UK, is greatly acknowledged. 


\section{References}

386 Bron, P. A., Marco, M., Hoffer, S. M., Van Mullekom, E., De Vos, W. M., \& Kleerebezem, M. (2004). Genetic characterization of the bile salt response in Lactobacillus plantarum and analysis of responsive promoters in vitro and in situ in the gastrointestinal tract. Journal of Bacteriology, 186(23), 7829-7835.

390

391

392

393

394

395

396

397

398

399

400

401

402

403

404

405

406

407

408

409

410

411

412

413

Bunesova, V., Musilova, S., Geigerova, M., Pechar, R., \& Rada, V. (2015). Comparison of mupirocin-based media for selective enumeration of bifidobacteria in probiotic supplements. Journal of Microbiological Methods, 109, 106-109.

Burgain, J., Scher, J., Lebeer, S., Vanderleyden, J., Cailliez-Grimal, C., Corgneau, M., Francius, G., \& Gaiani, C. (2014). Significance of bacterial surface molecules interactions with milk proteins to enhance microencapsulation of Lactobacillus rhamnosus GG. Food Hydrocolloids, 41, 60-70.

Chávarri, M., Marañón, I., Ares, R., Ibáñez, F. C., Marzo, F., \& del Carmen Villarán, M. (2010). Microencapsulation of a probiotic and prebiotic in alginate-chitosan capsules improves survival in simulated gastro-intestinal conditions. International Journal of Food Microbiology, 142(1), 185-189.

Clark, P. A., \& Martin, J. H. X. (1994). Selection of bifidobacteria for use as dietary adjuncts in cultured dairy foods. III. Tolerance to simulated bile concentrations of human small intestines. Cultured Dairy Products Journal, 29, 18-21.

Cook, M. T., Tzortzis, G., Khutoryanskiy, V. V., \& Charalampopoulos, D. (2013). Layer-bylayer coating of alginate matrices with chitosan-alginate for the improved survival and targeted delivery of probiotic bacteria after oral administration. Journal of Materials Chemistry $B, 1(1), 52-60$.

Donkor, O., Henriksson, A., Vasiljevic, T., \& Shah, N. (2006). Effect of acidification on the activity of probiotics in yoghurt during cold storage. International Dairy Journal, 16(10), 1181-1189.

Fritzen-Freire, C. B., Prudêncio, E. S., Amboni, R. D. M. C., Pinto, S. S., Negrão-Murakami, A. N., \& Murakami, F. S. (2012). Microencapsulation of bifidobacteria by spray drying in the presence of prebiotics. Food Research International, 45(1), 306-312. 
414 Gbassi, G. K., Vandamme, T., Ennahar, S., \& Marchioni, E. (2009). Microencapsulation of Lactobacillus plantarum spp in an alginate matrix coated with whey proteins. International Journal of Food Microbiology, 129(1), 103-105.

Gomes, A. M. P., Malcata, F. X., \& Klaver, F. A. M. (1998). Growth enhancement of Bifidobacterium lactis Bo and Lactobacillus acidophilus Ki by milk hydrolyzates. Journal of Dairy Science, 81(11), 2817-2825.

Gonzalez-Gonzalez, C. R., Tuohy, K. M., \& Jauregi, P. (2011). Production of angiotensin-Iconverting enzyme (ACE) inhibitory activity in milk fermented with probiotic strains: effects of calcium, $\mathrm{pH}$ and peptides on the ACE-inhibitory activity. International Dairy Journal, 21(9), 615-622.

Gougoulias, C., Tuohy, K. M., \& Gibson, G. R. (2008). Dietary-based gut flora modulation against Clostridium dificile onset. Food Science and Technology Bulletin: Functional Foods, 4(4), 31-41.

Guérin, D., Vuillemard, J. C., \& Subirade, M. (2003). Protection of bifidobacteria encapsulated in polysaccharide-protein gel beads against gastric juice and bile. Journal of Food Protection, 66(11), 2076-2084.

Hansen, L. T., Allan-Wojtas, P. M., Jin, Y. L., \& Paulson, A. T. (2002). Survival of Ca-alginate microencapsulated Bifidobacterium spp. in milk and simulated gastrointestinal conditions. Food Microbiology, 19(1), 35-45.

Kailasapathy, K. (2006). Survival of free and encapsulated probiotic bacteria and their effect on the sensory properties of yoghurt. LWT-Food Science and Technology, 39(10), 1221-1227.

Klemmer, K. J., Korber, D. R., Low, N. H., \& Nickerson, M. T. (2011). Pea protein-based capsules for probiotic and prebiotic delivery. International Journal of Food Science \& Technology, 46(11), 2248-2256.

Krasaekoopt, W., Bhandari, B., \& Deeth, H. (2003). Evaluation of encapsulation techniques of probiotics for yoghurt. International Dairy Journal, 13(1), 3-13.

Krasaekoopt, W., Bhandari, B., \& Deeth, H. (2004). The influence of coating materials on some properties of alginate beads and survivability of microencapsulated probiotic bacteria. International Dairy Journal, 14(8), 737-743. 
Krasaekoopt, W., Bhandari, B., \& Deeth, H. C. (2006). Survival of probiotics encapsulated in chitosan-coated alginate beads in yoghurt from UHT-and conventionally treated milk during storage. LWT-Food Science and Technology, 39(2), 177-183.

Lee, K. Y., \& Heo, T. R. (2000). Survival of Bifidobacterium longum immobilized in calcium alginate beads in simulated gastric juices and bile salt solution. Applied and Environmental Microbiology, 66(2), 869-873.

Li, X. Y., Chen, X. G., Cha, D. S., Park, H. J., \& Liu, C. S. (2009). Microencapsulation of a probiotic bacteria with alginate-gelatin and its properties. Journal of Microencapsulation, 26(4), 315-324.

Liserre, A. M., Ré, M. I., \& Franco, B. D. G. M. (2007). Microencapsulation of Bifidobacterium animalis subsp. lactis in modified alginate-chitosan beads and evaluation of survival in simulated gastrointestinal conditions. Food Biotechnology, 21(1), 1-16.

Maciel, G. M., Chaves, K. S., Grosso, C. R. F., \& Gigante, M. L. (2014). Microencapsulation of Lactobacillus acidophilus La-5 by spray-drying using sweet whey and skim milk as encapsulating materials. Journal of Dairy Science, 97(4), 1991-1998.

Martín-Diana, A. B., Janer, C., Peláez, C., \& Requena, T. (2003). Development of a fermented goat's milk containing probiotic bacteria. International Dairy Journal, 13(10), 827-833.

Özer, B., Kirmaci, H. A., Şenel, E., Atamer, M., \& Hayaloğlu, A. (2009). Improving the viability of Bifidobacterium bifidum BB-12 and Lactobacillus acidophilus LA-5 in white-brined cheese by microencapsulation. International Dairy Journal, 19(1), 22-29.

Pan, L. X., Fang, X. J., Yu, Z., Xin, Y., Liu, X. Y., Shi, L. E., \& Tang, Z. X. (2013). Encapsulation in alginate-skim milk microspheres improves viability of Lactobacillus bulgaricus in stimulated gastrointestinal conditions. International Journal of Food Sciences and Nutrition, 64(3), 380-384.

Prasanna, P. H. P., Grandison, A. S., \& Charalampopoulos, D. (2012). Effect of dairy-based protein sources and temperature on growth, acidification and exopolysaccharide production of Bifidobacterium strains in skim milk. Food Research International, 47(1), 6-12.

Prasanna, P. H. P., Grandison, A. S., \& Charalampopoulos, D. (2013). Microbiological, chemical and rheological properties of low fat set yoghurt produced with 
exopolysaccharide (EPS) producing Bifidobacterium strains. Food Research International, 51(1), 15-22.

Prasanna, P. H. P., Grandison, A. S., \& Charalampopoulos, D. (2014). Bifidobacteria in milk products: An overview of physiological and biochemical properties, exopolysaccharide production, selection criteria of milk products and health benefits. Food Research International, 55, 247-262.

Rajam, R., Karthik, P., Parthasarathi, S., Joseph, G., \& Anandharamakrishnan, C. (2012). Effect of whey protein-alginate wall systems on survival of microencapsulated Lactobacillus plantarum in simulated gastrointestinal conditions. Journal of Functional Foods, 4(4), 891-898.

Ranadheera, C. S., Evans, C. A., Adams, M. C., \& Baines, S. K. (2014). Effect of dairy probiotic combinations on in vitro gastrointestinal tolerance, intestinal epithelial cell adhesion and cytokine secretion. Journal of Functional Foods, 8, 18-25.

Ranadheera, C. S., Evans, C. A., Adams, M. C., \& Baines, S. K. (2015). Microencapsulation of Lactobacillus acidophilus LA-5, Bifidobacterium animalis subsp. lactis BB-12 and Propionibacterium jensenii 702 by spray drying in goat's milk. Small Ruminant Research, 123(1), 155-159.

Ranadheera, C. S., Liyanaarachchi, W. S., Chandrapala, J., Dissanayake, M., \& Vasiljevic, T. (2016). Utilizing unique properties of caseins and the casein micelle for delivery of sensitive food ingredients and bioactives. Trends in Food Science \& Technology, 57(Part A), 178-187.

Sandoval-Castilla, O., Lobato-Calleros, C., García-Galindo, H., Alvarez-Ramírez, J., \& Vernon-Carter, E. (2010). Textural properties of alginate-pectin beads and survivability of entrapped $\mathrm{Lb}$. casei in simulated gastrointestinal conditions and in yoghurt. Food Research International, 43(1), 111-117.

Shah, N. P. (2007). Functional cultures and health benefits. International Dairy Journal, 17(11), 1262-1277.

Shi, L. E., Li, Z. H., Li, D. T., Xu, M., Chen, H. Y., Zhang, Z. L., \& Tang, Z. X. (2013a). Encapsulation of probiotic Lactobacillus bulgaricus in alginate-milk microspheres and evaluation of the survival in simulated gastrointestinal conditions. Journal of Food Engineering, 117(1), 99-104. 
Shi, L. E., Li, Z. H., Zhang, Z. L., Zhang, T. T., Yu, W. M., Zhou, M. L., \& Tang, Z. X. (2013b). Encapsulation of Lactobacillus bulgaricus in carrageenan-locust bean gum coated milk microspheres with double layer structure. LWT-Food Science and Technology, 54(1), 147-151.

Shi, L. E., Zheng, W., Zhang, Y., \& Tang, Z. X. (2016). Milk-alginate microspheres: Protection and delivery of Enterococcus faecalis HZNU P2. LWT-Food Science and Technology, $65,840-844$.

Song, H., Yu, W., Gao, M., Liu, X., \& Ma, X. (2013). Microencapsulated probiotics using emulsification technique coupled with internal or external gelation process. Carbohydrate Polymers, 96(1), 181-189.

Sultana, K., Godward, G., Reynolds, N., Arumugaswamy, R., Peiris, P., \& Kailasapathy, K. (2000). Encapsulation of probiotic bacteria with alginate-starch and evaluation of survival in simulated gastrointestinal conditions and in yoghurt. International Journal of Food Microbiology, 62(1-2), 47-55.

Sun, W., \& Griffiths, M. W. (2000). Survival of bifidobacteria in yogurt and simulated gastric juice following immobilization in gellan-xanthan beads. International Journal of Food Microbiology, 61(1), 17-25.

Würth, R., Hörmannsperger, G., Wilke, J., Foerst, P., Haller, D., \& Kulozik, U. (2015). Protective effect of milk protein based microencapsulation on bacterial survival in simulated gastric juice versus the murine gastrointestinal system. Journal of Functional Foods, 15, 116-125.

Xiao, J., Kondo, S., Takahashi, N., Miyaji, K., Oshida, K., Hiramatsu, A., Iwatsuki, K., Kokubo, S., \& Hosono, A. (2003). Effects of milk products fermented by Bifidobacterium longum on blood lipids in rats and healthy adult male volunteers. Journal of Dairy Science, 86(7), 2452-2461.

Zou, Q., Zhao, J., Liu, X., Tian, F., Zhang, H., Zhang, H., \& Chen, W. (2011). Microencapsulation of Bifidobacterium bifidum F-35 in reinforced alginate microspheres prepared by emulsification/internal gelation. International Journal of Food Science \& Technology, 46(8), 1672-1678. 
538

539 
542 Fig.1. Scanning electron micrographs showing the surface morphology of different

544 legend explanations see Table1.

Fig. 2. Survival of free and encapsulated B. longum subsp. infantis CCUG 52486 in simulated gastric juice $(\mathrm{pH} \mathrm{2})$ at $37{ }^{\circ} \mathrm{C}$ for $120 \mathrm{~min}$. Vertical lines represent standard deviations. ${ }^{A B C D E}$ Means with different uppercase are significantly different $(p<0.05)$ between each time, for each type of alginate-dairy based microcapsule during the period of the analysis. ${ }^{\text {abcde }}$ Means with different lowercase are significantly different $(p<0.05)$ between each type of alginatedairy based microcapsule, for a particular time of the analysis. For legend explanations see Table1.

553

Fig. 3. Stability of free and encapsulated B. longum subsp. infantis CCUG 52486 in simulated intestinal juice $(\mathrm{pH} 7.5)$ at $37{ }^{\circ} \mathrm{C}$ for $120 \mathrm{~min}$. Vertical lines represent standard deviations. ${ }^{A B C D E}$ Means with different uppercase are significantly different $(p<0.05)$ between each time, for each type of alginate-dairy based microcapsule during the period of the analysis. ${ }^{\text {abcde }}$ Means with different lowercase are significantly different $(p<0.05)$ between each type of alginatedairy based microcapsule, for a particular time of the analysis. For legend explanations see 560 Table1.

561

562 Fig. 4. Changes in the viable count of free and the encapsulated $B$. longum subsp. infantis CCUG 52486 during refrigerated storage $\left(4{ }^{\circ} \mathrm{C}\right)$ for 28 days. Vertical

564 lines represent standard deviations. ${ }^{\mathrm{ABCDE}}$ Means with different uppercase are significantly 565 different $(p<0.05)$ between each time, for each type of alginate-dairy based microcapsule 566 during the storage. ${ }^{\text {abcd }}$ Means with different lowercase are significantly different $(p<0.05)$ 567 between each type of alginate-dairy based microcapsule, for a particular day of the storage 568 period. For legend explanations see Table1. 
570 Fig. 5. Changes in the viable counts free and encapsulated bacteria in goat milk at $4{ }^{\circ} \mathrm{C}$ for 28

571 days. Vertical lines represent standard deviations. ${ }^{A B C D E}$ Means with different uppercase are 572 significantly different $(p<0.05)$ between each time, for each type of alginate-dairy based 573 microcapsule during the storage. ${ }^{\text {abcd }}$ Means with different lowercase are significantly different $574(p<0.05)$ between each type of alginate-dairy based microcapsule, for a particular day of the 575 storage period. For legend explanations see Table1.

576

577

578

579

580

581

582

583

584

585 
Table 1. Encapsulation yield and size of different microcapsules

\begin{tabular}{lll}
\hline Type of microcapsules & Size $(\mathrm{mm})$ & Encapsulation yield $(\%)$ \\
\hline SA & $2.3 \pm 0.4^{\mathrm{b}}$ & $95.6 \pm 2.1^{\mathrm{a}}$ \\
SACM & $2.8 \pm 0.3^{\mathrm{a}}$ & $94.9 \pm 1.4^{\mathrm{a}}$ \\
SAGM & $3.1 \pm 0.2^{\mathrm{a}}$ & $95.3 \pm 1.6^{\mathrm{a}}$ \\
SACH & $2.4 \pm 0.4^{\mathrm{b}}$ & $94.1 \pm 2.7^{\mathrm{a}}$ \\
\hline
\end{tabular}

${ }^{\mathrm{ab}}$ Mean values ( \pm standard deviation) within the same column not sharing a common superscript differ significantly $(\mathrm{P}<0.05)$. SA: microcapsules were prepared using alginate. SACM: microcapsules were produced using alginate and cow milk at a ratio of 1.5:1 (v/v). SAGM: microcapsules were produced using alginate and goat milk at a ratio of 1.5:1 (v/v). SACH: microcapsules were prepared using alginate and casein hydrolysate at a ratio of 1.5:1 (v/v).

592

Table 2. Changes in the viability of free and encapsulated B. longum subsp. infantis CCUG 52486 in cow milk at $4{ }^{\circ} \mathrm{C}$ for 28 days.

\begin{tabular}{|c|c|c|c|c|c|}
\hline \multirow[t]{2}{*}{ Type of capsule } & \multicolumn{5}{|c|}{ Period of storage (days) } \\
\hline & 0 & 7 & 14 & 21 & 28 \\
\hline SA $\left(\log c f u g^{-1}\right)$ & $8.53 \pm 0.09^{\mathrm{A} a}$ & $8.05 \pm 0.09^{\mathrm{Ab}}$ & $7.38 \pm 0.09^{\mathrm{Bc}}$ & $6.84 \pm 0.40^{\mathrm{B} \mathrm{c}}$ & $6.03 \pm 0.04^{\mathrm{Cc}}$ \\
\hline SACM (log cfu g $\left.{ }^{-1}\right)$ & $8.57 \pm 0.11^{\mathrm{A} \mathrm{a}}$ & $8.42 \pm 0.05^{\mathrm{AB} \mathrm{a}}$ & $8.25 \pm 0.07^{\mathrm{BC} \mathrm{b}}$ & $8.13 \pm 0.11^{\mathrm{Cb}}$ & $7.07 \pm 0.15^{\mathrm{Db}}$ \\
\hline SAGM $\left(\log\right.$ cfu g $\left.{ }^{-1}\right)$ & $8.63 \pm 0.31^{\mathrm{Aa}}$ & $8.59 \pm 0.17^{\mathrm{A} \mathrm{a}}$ & $8.54 \pm 0.03^{\mathrm{Aa}}$ & $8.52 \pm 0.06^{\mathrm{Aa}}$ & $7.61 \pm 0.24^{\mathrm{B} \mathrm{a}}$ \\
\hline SACH $\left(\log \mathrm{cfu} \mathrm{g}^{-1}\right)$ & $8.49 \pm 0.03^{\mathrm{Aa}}$ & $7.63 \pm 0.06^{\mathrm{Bc}}$ & $6.93 \pm 0.18^{\mathrm{Cd}}$ & $6.38 \pm 0.38^{\mathrm{Cc}}$ & $5.50 \pm 0.05^{\mathrm{Dd}}$ \\
\hline Free Cells (log cfu mL $\left.L^{-1}\right)$ & $8.65 \pm 0.12^{\mathrm{Aa}}$ & $7.13 \pm 0.16^{\mathrm{Bd}}$ & $5.10 \pm 0.07^{\mathrm{Ce}}$ & $4.83 \pm 0.10^{\mathrm{Cd}}$ & $4.38 \pm 0.29^{\mathrm{D} \mathrm{e}}$ \\
\hline
\end{tabular}

${ }^{\mathrm{ABCD}}$ Means in the same row without common letter differ significantly $(p<0.05)$ for each type of microcapsules. ${ }^{\text {abcde }}$ Means in the same column for each type of microcapsule without common letter differ significantly $(p<0.05)$ for a particular day of storage. Data are expressed as mean \pm standard deviation. For legend explanations see 
600 Table 1.

601

602

603

604

605

606

607
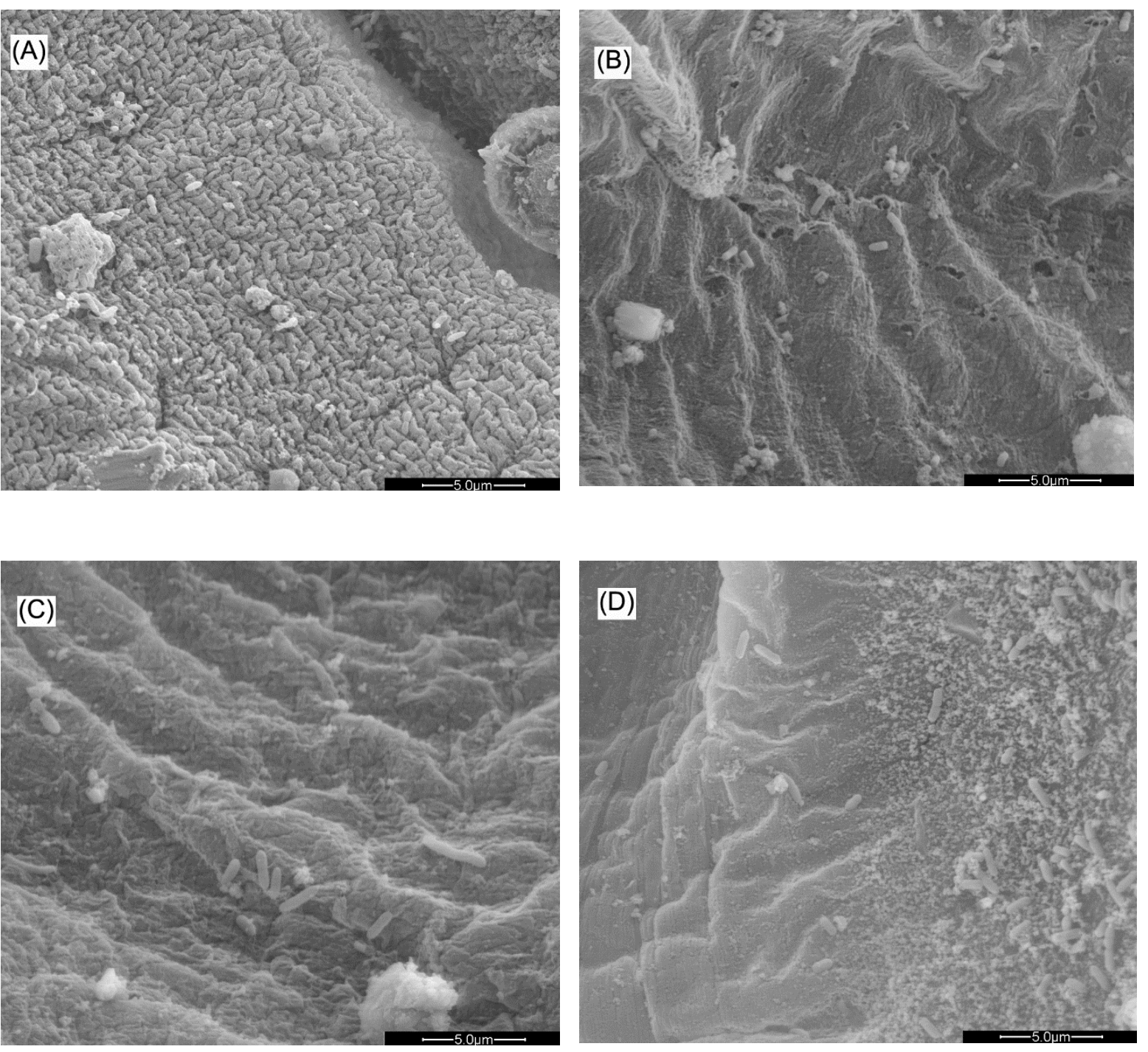

608 Fig.1.

609 
610

611

612

613

614

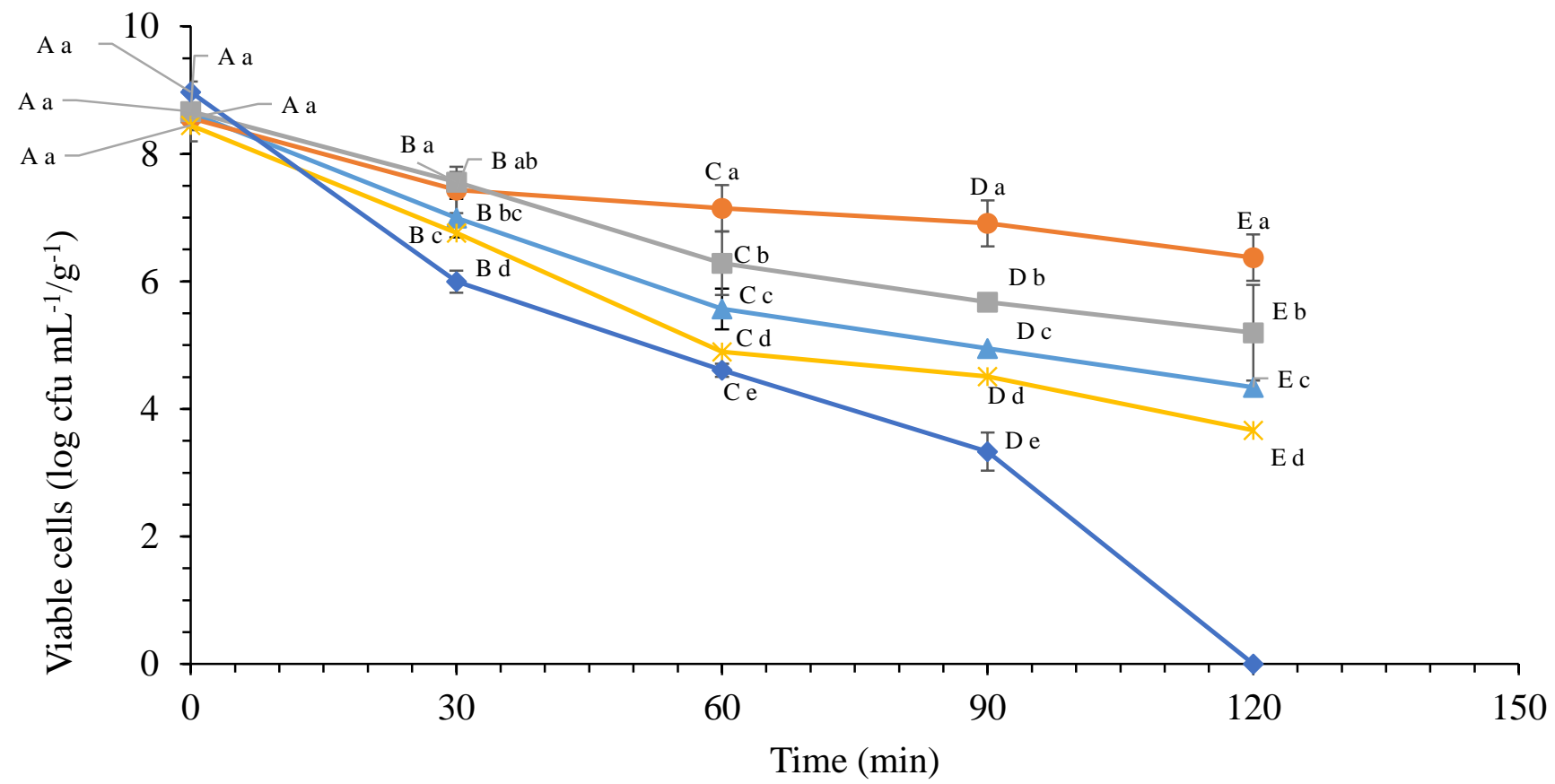

615

$\leftarrow$ SA $\rightarrow$ SACM $\leftarrow$ SAGM $\rightarrow$ SACH $\multimap$ Free Cells

616 Fig. 2.

617

618

619

620

621

622

623

624

625 


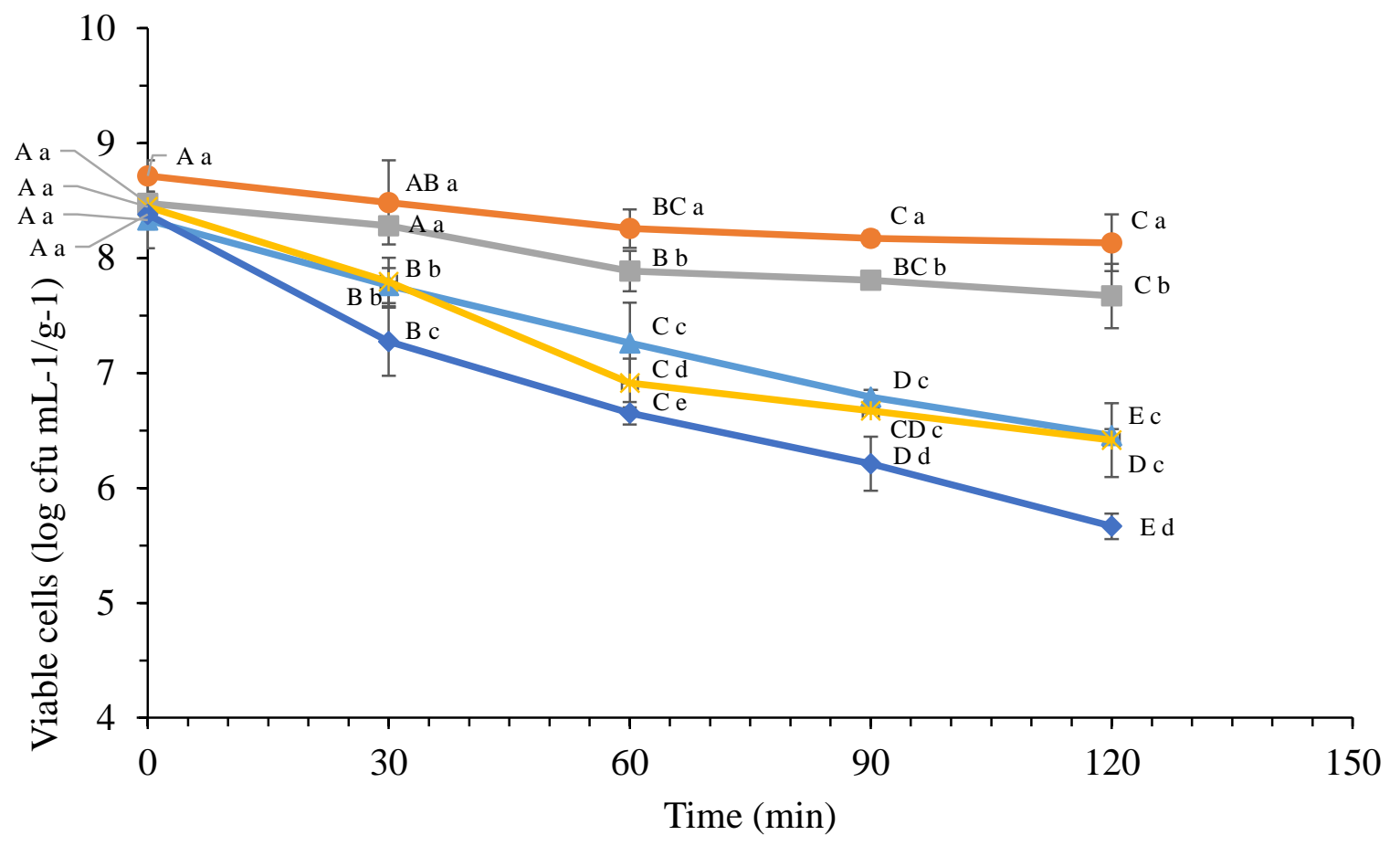

628

$\leftarrow$ SA $\rightarrow$ SACM $\rightarrow$ SAGM $\rightarrow$ SACH $\multimap$ Free Cells

629 Fig. 3.

630

631 


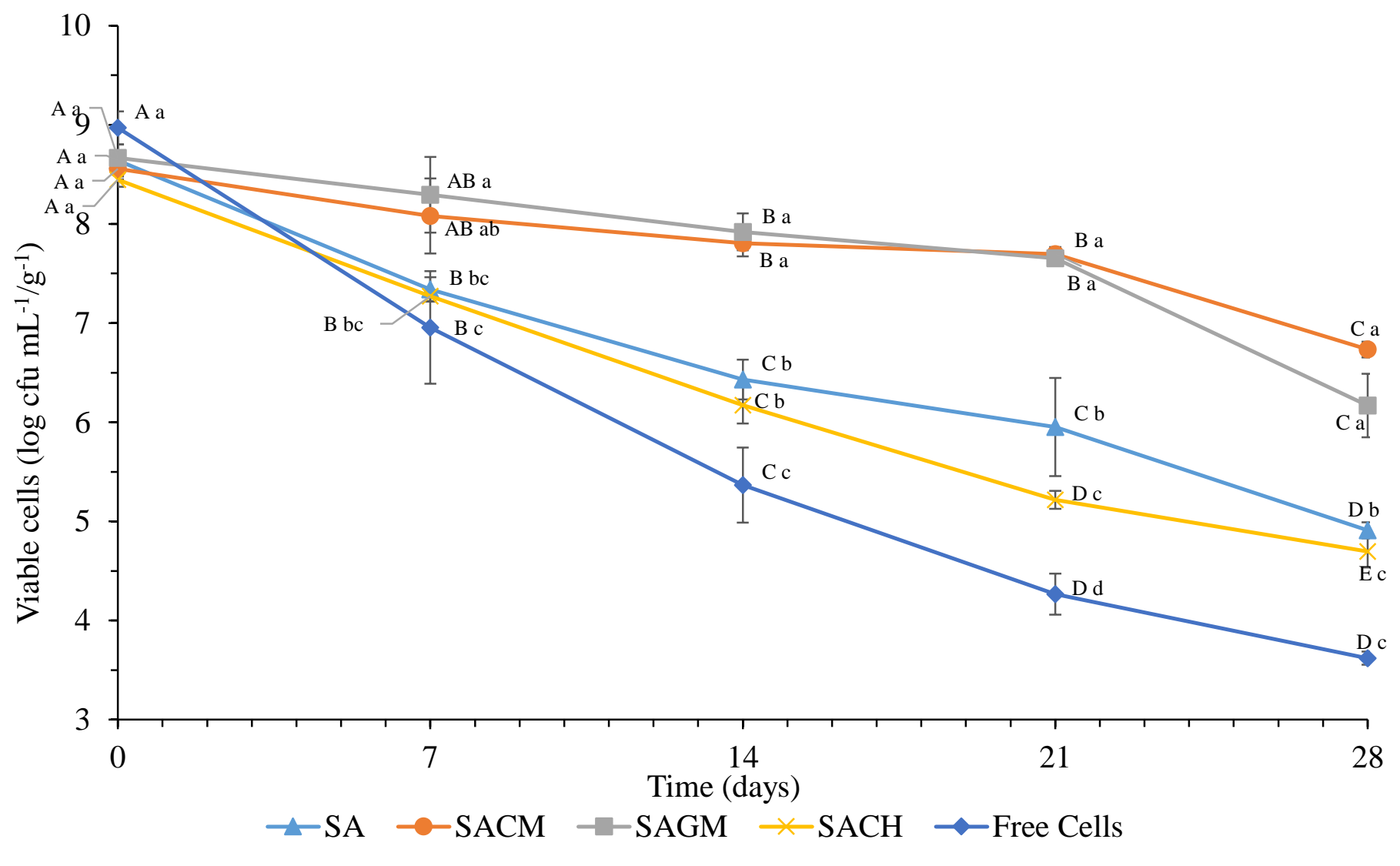

632

633 Fig. 4.

634

635 


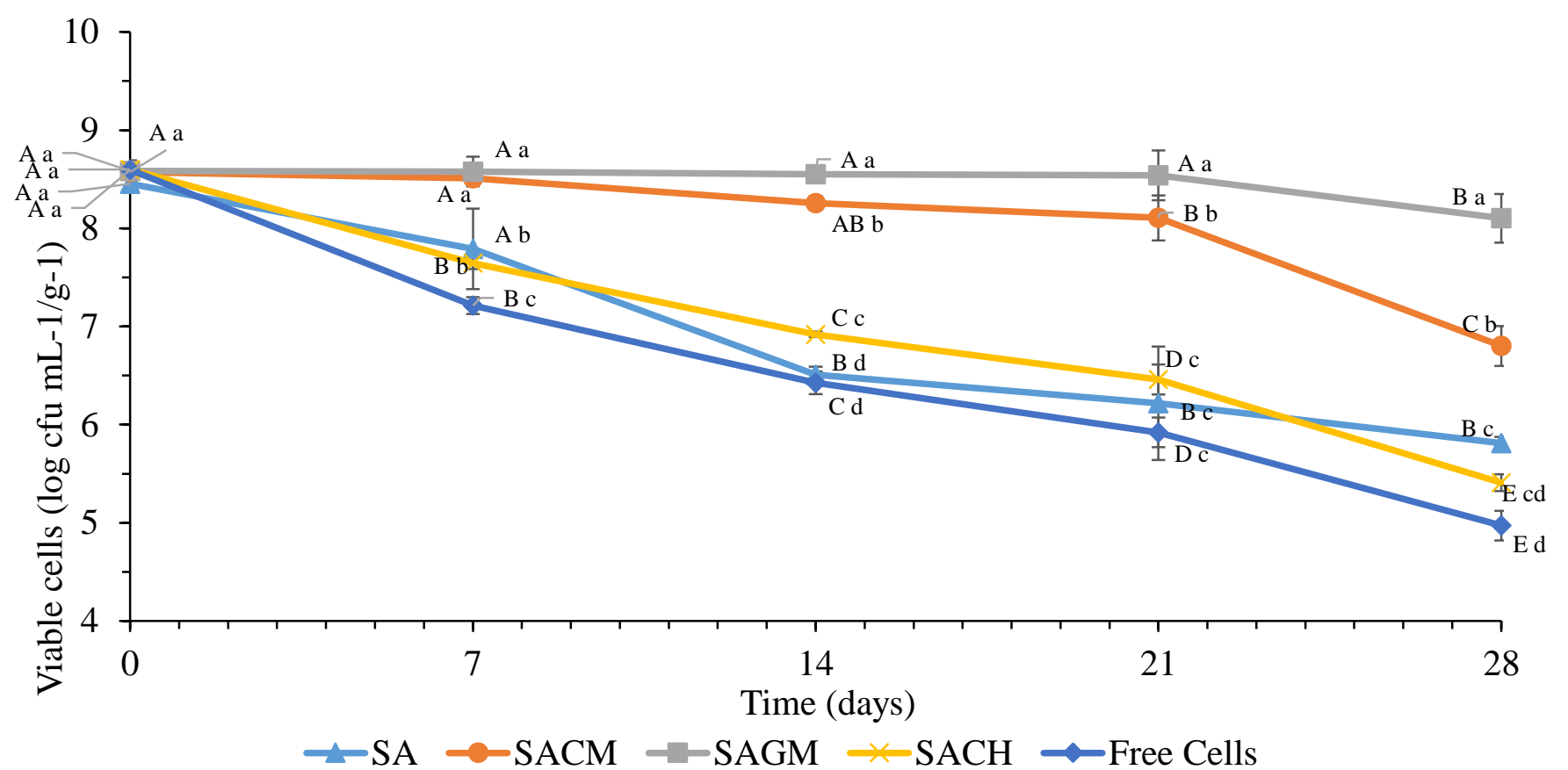

636

$637 \quad$ Fig. 5.

638

639

640

641

642 